\title{
"BOTIOM-UP" AND "TOP-DOWN" APPROACH FOR DEFINING ROAD SAFETY STRATEGY - CASE STUDY: CITY OF BELGRADE
}

\author{
Milan Vujanić ${ }^{1}$, Krsto Lipovac ${ }^{2}$, Dragan Jovanović ${ }^{3}$, Dalibor Pešić ${ }^{4}$, Boris Antić ${ }^{5}$ \\ 1,2,4,5 University of Belgrade, Faculty of Transport and Traffic Engineering, Vojvode Stepe 305, 11000 \\ Belgrade, Serbia \\ ${ }^{3}$ University of Novi Sad, Faculty of Technical Science, Trg Dositeja Obradovića 6, 21000 Novi Sad, \\ Serbia
}

Received 24 December 2012; accepted 21 January 2013

\begin{abstract}
The forming process of road safety strategy is quite complex because it implies a system approach that consists of several more or less complex steps. The analysis of the existing situation, defining the problem and creating a strategic document are the basic steps in forming road safety strategy. Each one of the mentioned steps involves several activities that must be carried out. Implementation, monitoring and revision are the next steps in a life cycle of the strategy, which provide continuous monitoring and adjustment of actions and programs for road safety improvement. In this study, on the example of the strategic document for the city of Belgrade, the concept of defining strategy and key areas of road safety strategy, which uses a "top-down" and "bottom-up" information flow approach, was shown. The specificity of strategy creation lays in the fact that the city of Belgrade consists of 10 urban and 7 rural municipalities, therefore it was necessary to find a model of strategic document that would include all the problems in the city but in also in all 17 municipalities. The model presented in this study provides the creation of a so-called overarching strategic document and 17 action plans, for each of the municipalities, and the overarching document is obtained by the so-called "overlap" 17 action plans.
\end{abstract}

Keywords: road safety strategy, road safety analysis, key areas, goals, action plan, activity plan, "top-down" and "bottom-up" approach.

\section{Introduction}

Today, strategic planning takes a larger part of transportation planning at all administrative levels, from urban, regional, up to national and international levels (Kölbl et al., 2008). Strategic action in road safety represents the highest level of road safety management (Vujanic et al., 2011). An effective road safety strategy is one of the most important tools in the ensuring progress. If there is a road safety strategy in a society, the society is considered to have a high awareness of road safety significance, what is one of the main prerequisites for road safety improvement. Road safety strategies aim to improve the three main factors: the behavior of road users, vehicles and the road environment (Wong et al., 2004).

Bearing in mind the complexity of traffic and traffic safety, today, strategic planning is facing huge challenges, and the first among them is to find the appropriate method for defining the structure and the content of strategic documents in the field of traffic safety.

\footnotetext{
${ }^{4}$ Corresponding author: d.pesic@sf.bg.ac.rs
} 
Besides that, when making strategic documents, it is of particular importance that a large number of stakeholders, as well as general public, are included and "involved" in the processes of formation, adoption, implementation, monitoring the effects, etc. In this way, we can obtain a higher awareness of the importance of traffic safety problems and ensure the implementation of measures and actions, provided by the strategic documents. Elvik (2008) also noted that, among other conditions, for the success of road safety management and the strategies, it's necessary to be strongly supported by the top management of government, as well as by the responsible agencies.

The life cycle of road safety management by strategic planning, using the approach "use of data for public health approach to road safety" (WHO, 2009), starts by definig the problems, then identifying the risk factors and priorities, defining the strategic document and in the end, setting the objectives and monitoring the performance of the strategic documents. Observing the methodology of strategic planning, researches (Kölbl et al., 2008) highlight the so-called feedback loop, which provides a comparison of the output results to the planned objectives. However, when referring to the established traffic safety management system, we can say that it is a continuous process. According to the previous statement, for the developing countries, Bener et al. (2003) gives a framework for the elements needed to make traffic safety a continuous cycle: goal setting, data collection and analysis, identification of measures, priority setting, which, on the other hand, involves the following steps: the formation, funding, implementation, monitoring and evaluation.

For effectiveness and efficiency of the strategy, beside the key factors: political will, adequate organization and knowledge, it is necessary to set not only qualitative but also quantitative objectives, so Elvik (1993) pointed out that the countries that have defined quantitative targets in their strategic documents achieved better results than the countries that have only qualitative objectives. Elvik (1993) also showed that the best results in traffic safety improving are achieved by strategies that have highly ambitious objectives. Also, for a road safety strategy to be successful, it is generally believed that realistic quantified road safety targets sholud be set (ETSC, 2003; Loo et al., 2005). Wong et al. (2006) said that a quantified road safety target is a number or index that is set by a national or local government to reduce the number of people who are killed or injured in road traffic accidents. Beside the output results, some of national road safety strategies, for example Japan and California, (Loo et al., 2005), have also targeted indicators (i.e. the percentage of safety belts use etc.).

Successful management of road safety, beside defining the objectives, according to the analysis made by Elvik (2008), also implies the necessity of fulfillment of conditions related to the strategies and objectives: acceptance by the government, defining challenging, but achievable objectives, defining fewer objectives, the existence of the authority for the agencies to implement measures in order to achieve the objectives, funding secured, the existence of monitoring and evaluation system for achieving objectives, motivating agencies to achieve objectives. Furthermore, Zang et al. (2006) and Timms et al. (2002) highlighted importance of adequate setting of objectives to achieve optimal transport strategies. On the other hand, among important reasons for unsuccessful road safety strategies and programs Elvik (2001) stated: lack of power, scarcity, social dilemmas and conflicting objectives. 
Measuring the success of the strategic management of traffic safety is also a major challenge and the way of measuring the effectiveness depends mostly on the defined key areas of strategy and the set objectives. Loo et al. (2005), based on good practices, define strenghts and weaknesses of the five most used evaluation approaches: simple comparison, statistical analysis, cost-benefit analysis, before-and-after analysis and trends of secondary parameters. On the other hand, Wong et al. (2006), also state some of the possible techniques of evaluation the success of the strategy: simple pre-post comparisons, pre-post comparisons with similar control areas, time-series analyses, multiple time series analyses with comparisons areas and weighted least-squares regressions. The most commonly used techniques for measuring the cost savings are: cost-effectiveness analysis, cost-utility analysis and cost-benefit analysis (Wong et al., 2006; WHO, 2010).

In this paper, a method of defining the strategy of road safety for the city of Belgrade is presented. The starting points for creating a road safety strategy can be found in the new Road Traffic Safety Law (RTSL) for the Republic of Serbia from the year 2009 (MoIRS, 2009), where the legislative provision stipulates the creation of traffic safety strategies at all levels. Bearing in mind the best world practices, strategy formation process is defined, from the identification of the current situation, defining the key areas, setting objectives, to monitoring the implementation and the success of the strategies in the field of road traffic safety.

This study does not analyze the validity and quality of data that define the current situation, nor the measures defined in key areas, but the study is focused on the process of strategy formation, that is, the steps that should be implemented in order to define the key areas and the objectives of the strategy. The basic characteristic, and therefore the additional problem of creating a road safety strategy for the city of Belgrade, the capital of Serbia, is that Belgrade consists of 10 urban and 7 rural municipalities. The diversity of the characteristics of the municipalities further complicates the definition of the appropriate strategy, so, for example, on the territory of some of the municipalities there is a highway, and on the others not, some municipalities do not have schools at all, some have agriculture as a main industry, and so on. Having in mind the complexity and the characteristics of each municipality individually, it was a big challenge to design and implement an approach so that the final output is a strategic document called "overarching" document on road safety, which would include all, or at least the key areas, of activities in road safety in all the municipalities in Belgrade. Because of the specificity of each of the municipalities, it was necessary to collect and analyze in details the information about the current state of traffic and traffic safety for all the municipalities individually, and then to define a strategy at the city level, and for each municipality to adopt an action plan, using the familiar concept of "bottom-up" and "top-down" perspectives (Timms, 2011).

\section{The Concept of Road Safety Strategy Creation for the City of Belgrade}

When setting up road safety strategy for the city of Belgrade, a detailed analysis of best practices in the strategic management of road safety had been done previously (DorsetCC, 2009; WHO, FIA and WB, 2010; Loo et al., 2005; WBG, 2008; ETSC, 2001; SafetyNet, 2009a; SafetyNet, 2009b). Common to all these documents is that the strategic management of traffic safety is one continuous 
cycle, or rather a loop that starts by analyzing the current situation, continues to setting goals and defining the measures, and after implementation, evaluation is done, and, at the end, the audit, which returns the loop to the beginning of the cycle.

Recognizing the common basis for all strategic documents studied, regardless of the level of organization (national, local, ...), considering the specifics of the city of Belgrade, the normative basis for Serbia and Belgrade, as well as other relevant facts, a concept of safety strategy formation process for the city of Belgrade is proposed (Fig. 1). The process consists of three steps: current situation analysis, defining the problems and proposing solutions.

The algorithm of the processes of road safety strategy formation (Fig. 1, hereinafter referred to as Algorithm) implies that before the formation of a strategic document it is necessary to carry out series of researches and detailed analyses. The basic requirement is to collect data on the existing situation, in order to note, the priorities of work. This analysis involves the implementation of various techniques and methods of data collection, and the selection of the methods used for data collection depends primarily on the level of the strategic document. Namely, on the lower level of the hierarchy the data need to be more detailed. For example, if a strategy document for a municipality is being defined, then, in order to define the strategic activities, it is necessary to know such details like the specific "black spots" of the municipality. On the other hand, a strategy document at national level doesn't have to contain those 'black spots", or the solutions for the 'black spots", noted at the municipality level. Besides that, for a specific municipality, there are specific data or specific problems, which could not be generalized on a higher level. In the next step, the algorithm involves the selection,

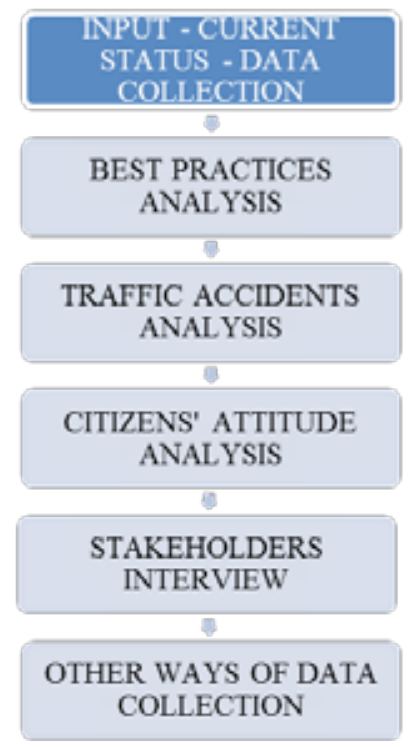

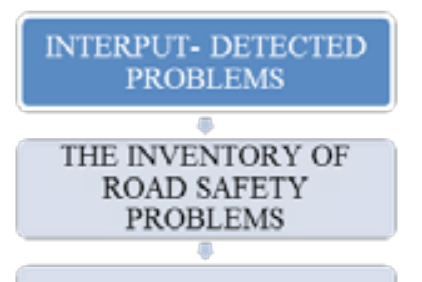

KEY AREAS OF ACTION
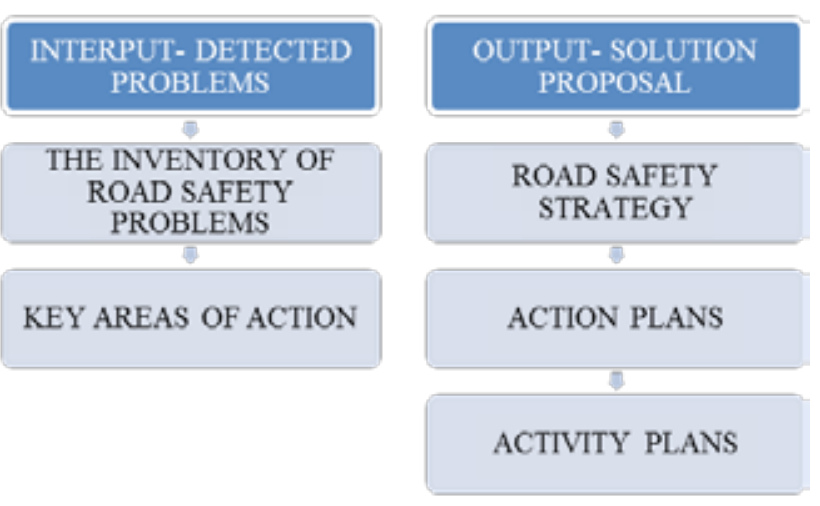

Fig. 1.

The Algorithm of the Processes of Road Safety Strategy Formation 
defining and grouping road safety problems. After recognizing the problems, the strategic document is being defined.

To form or create a strategy for the city of Belgrade, the so-called "top-down" and "bottom-up" model is implemented, which represents the so-called vertical flow of information, that are important for the functioning of the system (Fig. 2). The "initiative" to conduct analysis of the current condition, goes from the city to the municipalities, in order to form a strategy of road safety. Each one of the 17 municipalities conducts the appropriate analysis of the current situation (accident analysis, surveys, stakeholders' interview, etc.). These analyzes help each municipality to define problems and key areas for that municipality (horizontal arrows to the right), but also for the total analysis of the current situation for the whole city (a sort of sum of the previous analyzes by municipalities, vertical arrows). On a similar principle, furthermore, municipalities define their key areas and send them to the city, which uses a "cross section" to define key areas of the city. On the basis of the key areas defined in this way, the municipalities define their own action plans, which are an integral part of the city strategy, but also the basis to define the intersection of the common elements of the strategy.

After a detailed analysis of road safety in the 17 municipalities, the city defines the socalled general, that is, common goals related to the city and under the authority of the city administration, and then, in the backward step to the municipalities, incorporates the specificities of each municipality into specific action plans for each municipality. Action plans for each one of the municipalities are "small" strategic documents relating to a particular Municipality with all its features, specifics and details. These documents are extremely important for strategy implementing on a higher level, since it is necessary for all the municipalities to implement the defined actions, ensuring the success of the strategy. The significance of strategic documents or, at least, action plans, on the level of a municipality was confirmed by Wegman et al. (1991), who states that the political will, adequate organization and the

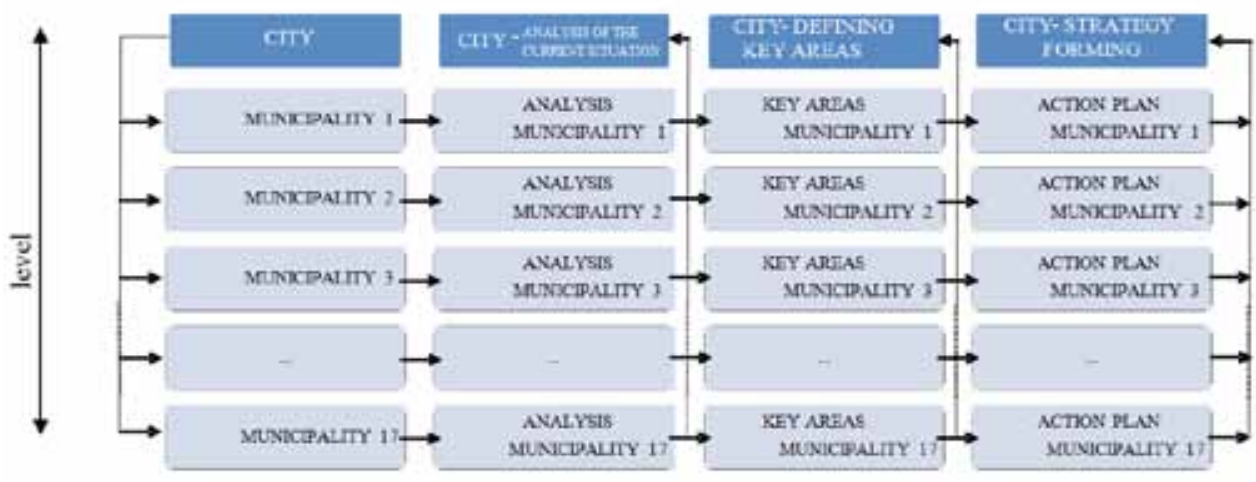

Fig. 2.

Vertical Information Flow - "Top-Down / Bottom-Up" Model 
necessary knowledge at the local level, is the key to the success of strategic documents and road safety improvement.

\section{The Steps in Forming the Road Safety Strategy Applying the "Top-Down" and "Bottom-Up" Concept}

The process of strategy forming basically consists of three main steps. These are: "input" - analysis of current situation (data collection and analysis of the required data), "interput" - defining key areas (defining the problem) and "output" - proposed solution (defining and making the final strategic document and action plans). In each of the steps it is necessary that the flow, processing and analysis of the data and defining the final output are done in accordance with the concept of "top-down" and "bottom-up". Practically, the "top" (or "up") is the city of Belgrade, and the "bottom" (or "down") are 17 municipalities. The "top" defines to the "down" what should be done (meaning, it defines that the "down", that is, "bottom" should carry out the necessary steps in order to create the strategy). The "bottom" carries out the activities defined for the level "bottom" (analysis of the current situation, defining the key areas, making action plans) and sends the processed and analyzed data to the "up", where the "up", that is, the "top" also carries out the activities defined for the level "top" (analysis of the current situation, defining the key areas, making strategic document). In this case, the "initiative" for carrying out the analysis of the current situation in order to form a strategy of road safety, goes from the city towards the municipalities. Each of the 17 municipalities implements the appropriate analysis of the current situation (analysis of accidents, examining the attitudes of citizens, stakeholders' interview, etc.). These analyzes are used by each one of the municipalities, in order to define its problems and key areas of the municipality, and also by the city, in order to make a comprehensive analysis of the current state. On a similar principle, furthermore, the municipalities define their key areas, and send them to the city, which uses a "cross section" to define its own key areas. Based on the key areas, the municipalities define their action plans, which are an integral part of the city strategy, but also the basis that provides that in the intersection of action plans of the municipalities, made by the city, the common elements of the strategy are defined.

\subsection{STEP - Defining the Current Situation - Data Collecting - INPUT}

The first step in defining the current situation is a research and a detailed analysis of the best practice in road safety strategy forming. It is necessary to analyze the existing ways of solving the observed problems, how the applied measures operate what are the effects and the results achieved. Namely, if there is a similar problem, which has already been solved, it is possible that the direct application of the solution would also give results in other conditions and circumstances, or the proposed measure might suffer certain modifications, or, for some reason, objective or subjective, a completely new measure would be applied in order to solve the identified problems. Bearing that in mind, during the preparation of the road safety strategic document for the city of Belgrade, a detailed analysis of several national and local strategies was done. Road safety strategic documents of some successful countries in the world (Japan, New Zealand, Sweden, etc.) (Loo et al., 2005) were analyzed, but also of the neighboring countries (Formal Yugoslav Republic of Macedonia, Montenegro) (RCRS, 2008; MoIaPA, 2009). For a complete understanding of 
the problem of road safety and defining the current situation it is necessary to know: final outcomes, exposure measures, intermediate outcomes, socio-economic costs of road traffic injuries and institutional delivery outputs (WHO, 2010). Experiences (WHO, FIA and WB, 2010) suggest that analysis of current situation includes: stakeholder analysis, evaluation of data sources and current system, evaluation of the needs of

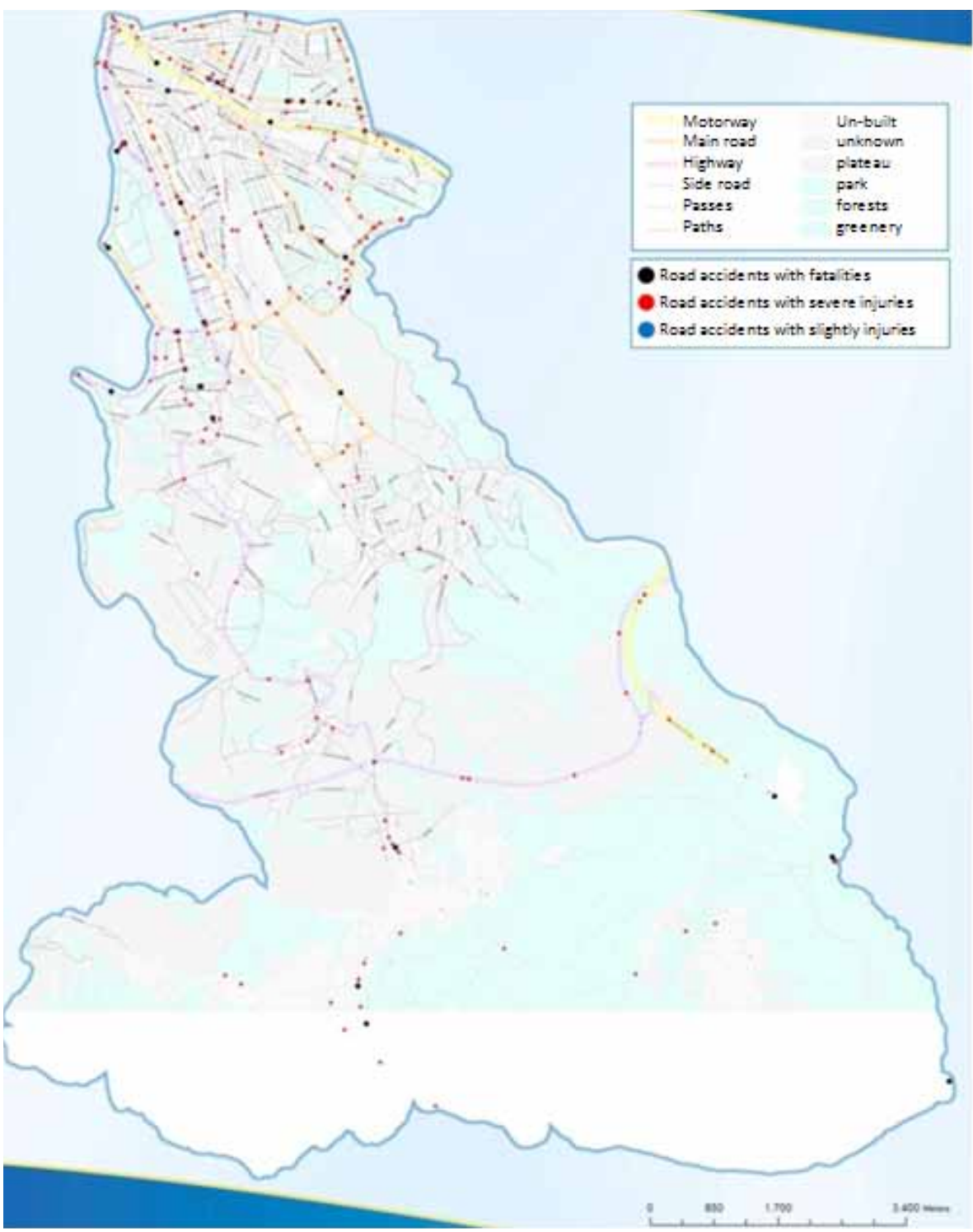

Fig. 3.

Example - Spatial Distribution of Accidents with Consequences in the Municipality of Vozdovac 
end users and environment analysis. Especially important is the quality of data describing the current situation. It is necessary to know the detailed definitions of basic terms, such as fatality, to have information of the socalled, underreporting accidents, to solve the problem of the data missing in the database and to find a way to overcome the possible errors that might occur in the database. The algorithm (Fig. 1), in the frame of the current situation analysis, includes an analysis of traffic accidents, which allows determination of the so-called objective risks. In other words, based on traffic accidents, the socalled spatial objective risk, can be defined, that is, the places where traffic participants vulnerability is increased, the so-called "black spots" (i.e. Fig. 3). Furthermore, it is possible to define the so-called time objective risk, that is, the time and the period when traffic vulnerability is increased (i.e. Fig. 4). Also, it is possible to perceive vulnerable road users (i.e. pedestrians, children, young drivers, etc.) (Table 1), and so on.

In the next step of the current situation analysis, the analysis of the attitudes of citizens is conducted in order to identify and define the so-called subjective risks in traffic. The subjective risks in traffic are nearly on the same level of importance as the objective ones, in terms of action (Vujanic et al., 2011). Therefore it is important to recognize and clearly define the subjective risks, because of the fact that their elimination also influences on the improvement of road

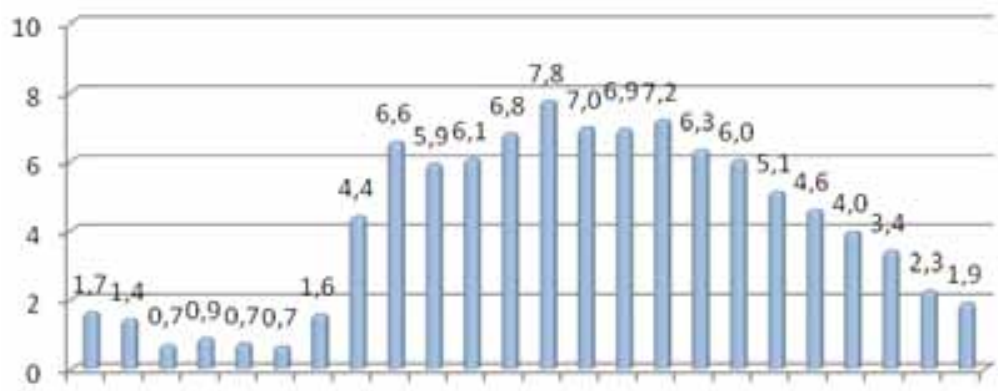

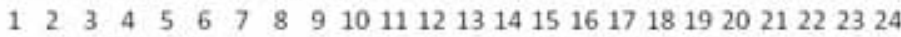

Fig. 4.

Example - Distribution of the Consequences of Accidents per Hours in the Municipality of Vozdovac

Table 1

Example - Distribution of Injuries per Traffic Participants

\begin{tabular}{|l|c|c|c|c|c|c|}
\hline & Fatalities & $\%$ & Seriously injured & $\%$ & Lightly injured & $\%$ \\
\hline Drivers & 16 & 29,1 & 145 & 40,4 & 411 & 37,6 \\
\hline Passengers & 8 & 14,5 & 72 & 20,1 & 424 & 38,8 \\
\hline Pedestrians & 31 & 56,4 & 142 & 39,6 & 259 & 23,7 \\
\hline Total & 55 & 100,0 & 359 & 100,0 & 1094 & 100,0 \\
\hline
\end{tabular}


safety (Pesic et al., 2012). For the purposes of Road safety strategies the city of Belgrade, 2011-2015 (Vujanic et al., 2011) in each one of the 17 municipalities, an anonymous telephone survey on a sample of 120 respondents was conducted, meaning, that there were 2040 respondents in Belgrade. The survey contained 35 questions, and the citizens were, among other things, asked to: define critical elements related to driving, cycling and walking, and potential hazardous sites, in terms of unsafe behavior. Analysis of the survey results was also taken into account when defining the inventory problem of road safety, which, on the other hand, was the basis for defining key areas of the strategy intervention. The survey, that is, the interview of the interested parties (stakeholders), has a great importance in establishing and defining road safety problems. The reports, obtained from the opinions, observations, experiences, and the problems identified by: municipal authorities, schools, driving schools, public companies engaged in transportation of freight and passengers, traffic police and other entities are processed and recorded in the form of road safety problems. It is especially important in this part to emphasize that the problem has to be "called by its real name" in order to be solved. Namely, it is possible that an elementary school sent a letter to the municipality informing them about the problem in the lack of speed bumps in front of the school. However, the problem is not the lack of speed bumps in a school zone, but the vulnerability of children due to the high speed of vehicles in school zones. This example indicates not only that a problem was defined incorrectly, but also that it is of great importance that the "problems" in road safety identified by the stakeholders should be properly defined, and this requires that a team of experts recognizes the problem and defines it correctly.
For the purpose of defining an inventory of road safety problems in the municipalities, the form of the questionnaire shown in Table 2 was used.

As a part of the process of creating a strategic document in each municipality, the so-called working group, consisting of at least three members, a representative of the traffic police and representatives of municipal government in charge of transport, was defined. The working group was tasked to prepare an inventory of road safety problems, bearing in mind: the experience of the municipal government demands of citizens regarding road safety, the transporters' experiences, preschool institutions' experiences, experiences of health care institutions, schools' experiences, experiences of driving schools and so on. Also, the working group has conducted SWOT (Strength-Weakness-Opportunity-Treat) and PESTEL (Political-Social-EconomicTechnological-Environmental-Legal Analysis) analysis of the transport system in each municipality. An example of the SWOT analysis for the municipality of Vozdovac is given in Table 3.

Similarly to what was said in WHO, FIA and WB (2010) one of the steps in evaluation of the current situation is the evaluation of the end users' needs, that involve not only the stakeholders but also the road users, and all in order to understand the state of traffic safety better, to evaluate the needs and define the financial and human resources necessary for solving these problems. The methods suggested for assessing the needs of end users are: surveys, in-depth interviews, focus group discussions, observation of user behavior, analysis of requests for information to agencies and libraries, library reports and a working group or committee review. Beside these methods of data collection, analyzing 


\section{Table 2}

The Form of the Questionnaire for Defining Road Safety Problems by the Stakeholders in a Municipality

\begin{tabular}{|c|c|c|c|}
\hline $\begin{array}{l}\text { THE GROUP OF } \\
\text { PROBLEMS }\end{array}$ & $\begin{array}{c}\text { THE } \\
\text { PROBLEM }\end{array}$ & THE SUBPROBLEM & $\begin{array}{l}\text { A DETAILED } \\
\text { DESCRIPTION }\end{array}$ \\
\hline \multirow[b]{2}{*}{ EDUCATION } & $\begin{array}{c}\text { preschool and } \\
\text { school children }\end{array}$ & - regular classes in traffic safety & \\
\hline & drivers & $\begin{array}{l}\text { - } \text { special programs for young drivers and beginners } \\
\text { - training for drivers who often make violations } \\
\text { - defensive driving training } \\
\text { - professional drivers' training }\end{array}$ & \\
\hline \multirow{6}{*}{ INFRASTRUCTURE } & roads and streets & $\begin{array}{l}\text { - intersections (the method of regulating, geometry, } \\
\text { traffic volume, lighting) } \\
\text { - sections (the method of regulating, geometry, traffic } \\
\text { volume, lighting) } \\
\text { - other forms of transport (rail, ...) }\end{array}$ & \\
\hline & parking & $\begin{array}{l}\text { - improper parking (visibility interference) } \\
\text { - lack of capacity }\end{array}$ & \\
\hline & $\begin{array}{c}\text { vulnerable road } \\
\text { users }\end{array}$ & $\begin{array}{l}\text { - pavements and paths for pedestrians (especially } \\
\text { in the areas of kindergartens, schools), if there are } \\
\text { enough of them and what condition are they in } \\
\text { - pavements occupied by buildings } \\
\text { - parked vehicles pedestrian crossings (if there are } \\
\text { enough of them and whether the position is in } \\
\text { accordance with the needs of pedestrians) } \\
\text { - pedestrian crossings' signal and lighting }\end{array}$ & \\
\hline & public transport & $\begin{array}{l}\text { - suitability of lines, number, vehicle type, stops, } \\
\text { niches, lighting, signs }\end{array}$ & \\
\hline & traffic regulation & $\begin{array}{l}\text { - compliance with the requirements } \\
\text { - unclear regulation } \\
\text { - the needs for regulation change }\end{array}$ & \\
\hline & the rest & & \\
\hline
\end{tabular}


and defining the current situation, it is possible to spot problems using other research techniques: scientific observation, experiment, measurement, conflict technique, etc. These methods generally recognize and measure indicators, or the so-called road safety indicators (i.e. the percentage of seat belt use, the percentage of drivers exceeding the speed limit, the number and severity of conflicts, etc.). The importance of road safety indicators is reflected in the fact that it is not necessary to wait for traffic accidents happen, but based on the identified unsafe behaviors or indicators, the level of road safety can be estimated or defined.

A quality defined current situation creates a real opportunity to make potential aims in the future. It is preferable to set quantitative goals, based on the defined current situation, and experiences in the world indicate that highly set targets motivate the society and the other interested parties to reach them, and in that way, better results regarding road safety improvement are also achieved (Elvik, 2008; Broughton et al., 2000; Rumar, 2002).

\subsection{STEP - The Identified Problems - INTERPUT}

Based on the previous comprehensive analysis of the current state, problems in road safety, or the so-called inventory of road safety problems, are defined, both at the level of a municipality, and then at the city level. After the current situation analysis we may be able to identify risk factors and risk areas, that is, road safety problems (WHO, FIA and

\section{Table 3}

\section{An Example of the SWOT Analysis for One of the Municipalities}

\begin{tabular}{|c|c|}
\hline $\begin{array}{l}\text { - The existence of legal support } \\
\text { - Political support - a body established for the purpose } \\
\text { of road safety } \\
\text { - Professional competence of the team } \\
\text { - Willingness of local government to implement the } \\
\text { action plan }\end{array}$ & $\begin{array}{l}\text { W } \\
\text { - Lack of competence in the field of traffic operations } \\
\text { at local level } \\
\text { - Lack of traffic signals } \\
\text { - Insufficiently developed road infrastructure } \\
\text { - Infrastructure unsuitable for various needs (persons } \\
\text { with special needs, children, ...) } \\
\text { - Control of access to the roads of the high profile } \\
\text { - The independence of the body dealing with traffic } \\
\text { and traffic safety }\end{array}$ \\
\hline $\begin{array}{l}\text { O } \\
\text { - Road Safety Strategy } \\
\text { - Cooperation with the Secretariat of Transportation } \\
\text { (local city government) } \\
\text { - Interest of school and preschool institutions for the } \\
\text { education of children } \\
\text { - Interest of local government } \\
\text { - Cooperation with other stakeholders (Ministry of } \\
\text { Interior, Traffic Police, Transporters, Ambulance, Fire } \\
\text { Brigade, other companies and institutions) } \\
\text { - Steady (continuous) campaign on traffic safety } \\
\text { - Media support } \\
\text { - Training / additional training of local authorities } \\
\text { - Better use of Beovoz (local light train and metro) }\end{array}$ & $\begin{array}{l}\text { T } \\
\text { - Unstable political situation } \\
\text { - Complex user requirements } \\
\text { - Slow implementation of the Law } \\
\text { - Lack of funding for the implementation of the } \\
\text { planned actions } \\
\text { - Improper use of funds } \\
\text { - Slowness in resolving property issues } \\
\text { - Slowness in obtaining building permits }\end{array}$ \\
\hline
\end{tabular}


WB, 2010). The problems in road safety are grouped into key areas that road safety strategy should be dealing with. When defining the key areas it is necessary, above all, to make sure that the number of key areas is of acceptable proportions. In other words, when road safety problems are being identified, it is necessary to define several key areas that the strategy will basically deal with, and not to define dozens of key areas. Defining a large number of key areas prevents and makes it difficult not only to look at road safety problems in general, but also to direct the measures and actions, which was confirmed by Elvik (2008).

Key areas in most strategic documents with the best practice (Loo et al., 2005) are: safer drivers, safer vehicles, safer infrastructure, speeds, vulnerable road users, education, enforcement, etc. Key areas of Road Safety Strategy for the city of Belgrade substantially do not differ a lot from the key areas that the best world strategies recognized as a problem. Because of the specificity of the city of Belgrade and the specifities of each of the municipalities, it is possible that some municipality has one or more key areas different than the city, but still, we should aim to harmonize the key areas at the city level. Namely, for example, as rural municipalities, differently to the urban ones, have problems with agricultural machinery in traffic, one of the key areas for rural municipalities would be the safety of agricultural machinery, whereas for the urban municipalities that would not be the case. Differences can be overcome, i.e. that the problem of agricultural machines isn't defined at the city level, but through the Action plans and the Activities' plans of the municipalities that have this kind of problems. In the case of Belgrade, on the basis of comprehensive analysis of the current state the following key areas are defined:
- protection system - the organization of road safety,

- $\quad$ safer drivers,

- road safety promotions,

- $\quad$ safer infrastructure.

The protective system is the most important part of road safety strategies of Belgrade, because the formation, establishment and strengthening of institutional capacity provides the basis and precondition for the successful implementation of strategic plans for road safety improvement. It was noted that in Serbia, and in the world, the most vulnerable categories of road users, and also the category that most contributes to traffic safety, are the drivers. Therefore, the strategic document highlighted the problem of drivers' insecurity. Bearing in mind that by road safety promotions, with minimal investment in road safety, can be achieved much more (cost-effective measures; Elvik and Vaa, 2004), we come to the conclusion that road safety promotions, that include: campaigns, actions, lectures, etc., also represent an important key area of road safety strategies for the city of Belgrade. The importance of infrastructure is clearly recognized, but from the aspect of road safety, it is not crucial that infrastructure only exists, but that is adapted to different needs, users, etc. The problems of vulnerable road users, public transport safety, the impact of parking on road safety, law enforcement, etc., can be emphasized as other important activities.

\subsection{STEP - Proposed Solutions - OUTPUT}

The previous steps in the formation of road safety strategy are aimed at recognizing, defining and clarifying road safety problems, and defining key areas, which will be considered specifically and in detail 
by the road safety strategy. Knowing the problem makes it possible to give a proposal for its removal. Knowing the problems of each municipality individually make it is possible to define action plans for each municipality. The Action plan is a set of measures and actions that are used in order to achieve the projected goal (Loo et al., 2005). Establishment of action plans at the level of the municipality is a defined course of action on key areas for each municipality. The City strategy will practically represent a 'cross section" of action plans of the municipalities (Fig. 5). In other words, a common problem for all the municipalities will be a problem which will be located in the city's road safety strategy, and the special problems, beside the common problems, will reside in the action plans of the municipalities.

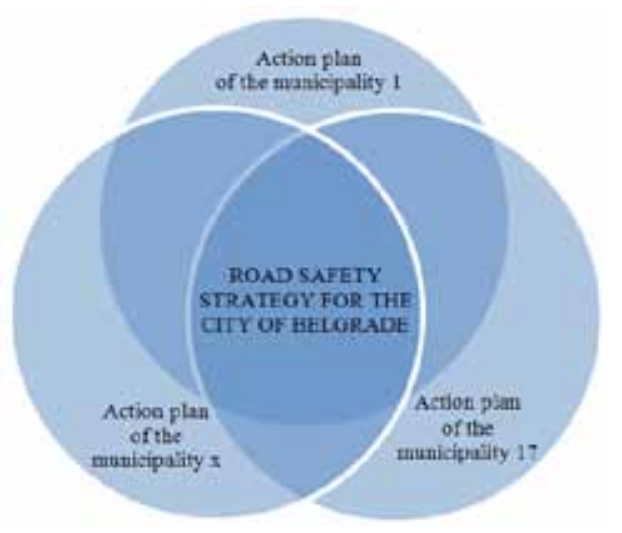

Fig. 5.

The Cross Section of the Action Plans
Within the action plans for each municipality individually, activity plans, which represent the concrete measures and activities to be implemented at the level of a municipality, in order to achieve the goal of the strategy, are also defined. Activity plans are prepared for all the key areas, and each one of the activity plans includes a series of measures and actions aimed at achieving the goal of road safety strategy for the city of Belgrade. Activity plans include: a specific activity, action or measure; the main participant; other participants in the implementation of the activity; target date for achieving the activity, as well as the estimated costs of the activity implementation (Fig. 6).

Within the road safety strategy for the city, but also within the action plans for each one of the municipalities, it is necessary to define the so-called quantitative goal, beside the qualitative one. Quantitative goals show political will and commitment and motivate all stakeholders to achieve the set of goals. A review of the good practices (Australia, California, The Great Britain, Japan, New Zealand and Sweden) in Loo et al. (2005) leads authors of the present study to the conclusion that in most cases, high goals of strategies were set, and they vary for example from 40 to $50 \%$ reduction of fatalities in road accidents in the ten-year period.

Following the example of the developed countries, in the road safety strategy for the city of Belgrade for the period 2011-2015

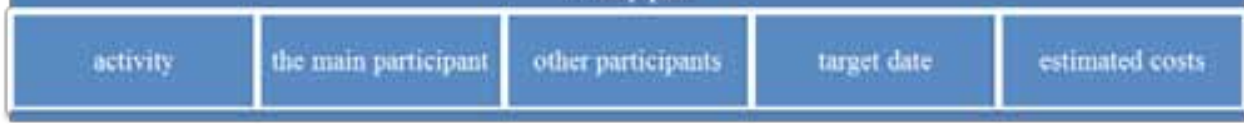

Fig. 6.

Activity Plan 
(Vujanic et al., 2011), a quantitative goal, the so-called "50\% less" was set. Beside the basic one, it is necessary to define several related goals for the strategy of the city of Belgrade. Similarly, regarding the goals, Elvik (2008) also stated. Specifically, based on the so-called overall target, a set of targets has been developed for various road safety indicators and the defined objectives cover all the important issues of road safety.

In Belgrade, for example, about 150 people a year is killed in traffic accidents, and the goal is that in 2015 that number is halved, i.e. that 75 persons are killed in road accidents. The related goals (the number of injuries, the percentage of seat belts use) are defined in accordance with the purpose, vision and mission of the strategy. One of the related goals of the strategy, at the city level, is to reduce the number of persons seriously injured in road accidents by $20 \%$.

Action plans for each one of the municipalities also have defined goals that are consistent with the Strategy. So, beside the main target, related to fatalities reducing by $50 \%$, there are the related targets regarding the increasing of the percentage of seat belt use from the current $50 \%$ to the projected $90 \%$ for the year 2015 , reducing the number of drivers who do not respect the speed limit from the current $20 \%$ to projected $10 \%$ in 2015, and so on.

\subsection{Evaluation of the Strategy Implementation Effects}

For the evaluation of the strategic documents effects, different techniques are used, and generally, they can be divided into two groups. The first group consists of those techniques related to the detection of changes related to the outputs (fatalities, accidents, etc.) and the intermediate outputs (seat belts, conflicts, etc.), and some of them are: simple comparison, statistical analysis, before-and-after analysis, trends and analysis of secondary parameters, and the second group consists of techniques that define the cost savings, such as: cost-effectiveness analysis, cost-utility analysis and cost-benefit analysis (Wong et al., 2006; WHO, FIA and WB, 2010).

Goals achievement can be monitored through the effects, but it is important to define the indicator that could be used to monitor the objective of the strategy. In this sense, the effects are divided into three levels. The first level represents the effects regarding the changes in the behavior of road users and the selected indicators are: the percentage of use of safety belts on front seats, the percentage of drivers exceeding the speed limit, the percentage of drivers who drive under the influence of alcohol (Table 4). On the second level the effects are measured on the basis of reducing the number of accidents and their consequences, especially fatalities, and injured persons in particular (Table 5). On the third level of defining the effects the savings in social costs of traffic accidents are measured (Table 6). The effects are measured based on the estimated, that is, the target values of the appropriate indicators.

The reduction of total social costs incurred as a result of traffic accidents are also the expected benefits from implementation of the Action Plan and to assess the costs incurred as a result of traffic accidents the PIARC's costing model (PIARC, 2003) was used.

By defining goals and related objectives, indicators to be used for monitoring and measuring the effects of the strategy 


\section{Table 4}

The Expected Benefits - Level I (Changes in the Behavior of Road Users)

\begin{tabular}{|l|c|c|c|c|c|c|c|}
\hline $\begin{array}{l}\text { The behaviour } \\
\text { of road users - } \\
\text { indicator }\end{array}$ & $\mathbf{2 0 0 9}$ & $\mathbf{2 0 1 1 / 2 0 0 9}$ & $\mathbf{2 0 1 2 / 2 0 1 1}$ & $\mathbf{2 0 1 3 / 2 0 1 2}$ & $\mathbf{2 0 1 4 / 2 0 1 3}$ & $\mathbf{2 0 1 5 / 2 0 1 4}$ & $\begin{array}{c}\text { The expected effects } \\
\text { - total 2015/2009 }\end{array}$ \\
\hline $\begin{array}{l}\text { The percentage of } \\
\text { use of safety belts } \\
\text { on front seats }\end{array}$ & $50 \%$ & $+25 \%$ & $+20 \%$ & $+10 \%$ & $+5 \%$ & $\begin{array}{c}\text { the percentage of } \\
\text { use of safety belts on } \\
\text { front seats increased } \\
\text { to over } 90 \%\end{array}$ \\
\hline $\begin{array}{l}\text { The percentage of } \\
\text { drivers exceeding } \\
\text { the speed limit }\end{array}$ & $20 \%$ & $-15 \%$ & $-15 \%$ & $-15 \%$ & $-10 \%$ & $-10 \%$ & $\begin{array}{c}\text { the percentage of } \\
\text { drivers exceeding } \\
\text { the speed limit } \\
\text { decreased to } 10 \%\end{array}$ \\
\hline $\begin{array}{l}\text { The percentage of } \\
\text { drivers who drive } \\
\text { under the influence } \\
\text { of alcohol }\end{array}$ & $10 \%$ & $-15 \%$ & $-15 \%$ & $-15 \%$ & $-10 \%$ & $-10 \%$ & $\begin{array}{c}\text { the percentage of } \\
\text { drivers who drive } \\
\text { under the influence } \\
\text { of alcohol decreased } \\
\text { to } 5 \%\end{array}$ \\
\hline
\end{tabular}

Table 5

The Expected Benefits - Level II (The Effects in Reducing the Number and Consequences of Accidents)

\begin{tabular}{|l|c|c|c|c|c|c|c|}
\hline $\begin{array}{l}\text { The number and } \\
\text { consequences } \\
\text { of accidents - } \\
\text { indicator }\end{array}$ & $\mathbf{2 0 0 9}$ & $\mathbf{2 0 1 1}$ & $\mathbf{2 0 1 2}$ & $\mathbf{2 0 1 3}$ & $\mathbf{2 0 1 4}$ & $\mathbf{2 0 1 5}$ & $\begin{array}{c}\text { The total decrease } \\
\text { expected in the } \\
\text { period from 2011 } \\
\text { to 2015 compared } \\
\text { to 2009 }\end{array}$ \\
\hline $\begin{array}{l}\text { The number of } \\
\text { accidents }\end{array}$ & 2395 & 2000 & 1600 & 1400 & 1300 & 1197 & 4478 \\
\hline $\begin{array}{l}\text { The number of } \\
\text { persons killed in } \\
\text { accidents }\end{array}$ & 7 & 6 & 5 & 5 & 4 & 3 & 12 \\
\hline $\begin{array}{l}\text { The number of } \\
\text { persons injured in } \\
\text { accidents }\end{array}$ & 382 & 330 & 290 & 250 & 220 & 191 & \\
\hline
\end{tabular}

\section{Table 6}

The Expected Benefits - Level III (The Effects in Reducing the Costs of Traffic Accidents)

\begin{tabular}{|c|c|c|c|c|c|c|}
\hline \multirow{2}{*}{$\begin{array}{c}\text { The savings in costs } \\
\text { incurred as a result } \\
\text { of traffic accidents } \\
\text { (euros) }\end{array}$} & $\mathbf{2 0 1 1 / 2 0 0 9}$ & $\mathbf{2 0 1 2 / 2 0 0 9}$ & $\mathbf{2 0 1 3 / 2 0 0 9}$ & $\mathbf{2 0 1 4 / 2 0 0 9}$ & $\mathbf{2 0 1 5 / 2 0 0 9}$ & $\begin{array}{c}\text { Total expected } \\
\text { benefit - } \\
\text { savings in the } \\
\text { period 2011- } \\
\text { 2015 }\end{array}$ \\
\cline { 2 - 7 } & $4.387 .074,17$ & $6.804 .213,32$ & $9.442 .419,51$ & $11.476 .340,92$ & $12.085 .061,95$ & $44.195 .109,88$ \\
\hline
\end{tabular}


implementation and road safety improvement are also defined. It can be concluded that without well-defined indicators for monitoring the effects and their measurement it cannot be determined whether the strategy document and its application gave results in terms of road safety improvement.

\section{Conclusion}

The importance of strategic management in road safety is reflected in achieving the objectives that contribute to road safety improvement through fewer accidents, less consequences of accidents, safer behavior of road users, etc. In order to form, or define road safety strategy, first, it is necessary to have a qualitative analysis of the current state, which can be implemented in different ways and in combination of ways and techniques simultaneously.

The output from the qualitative analysis of the current situation involves a precise definition of the road safety problems, and therefore the definition of key areas, that the road safety strategy would deal with. Based on the defined key areas, specific activities and actions are determined, but also the main participants, other participants, the target date for activity implementation, as well as the expected costs of realization of the specific activity. This way of establishing action plans for the city of Belgrade will cover both the action plans at the level of the municipalities and the main strategic document, the "Road Safety Strategy for the city of Belgrade".

The strategy for the city of Belgrade includes all common problems in all the municipalities, and each action plan for a municipality includes both common and specific problems and activities. Analysis of the current state represents the input for subsequent steps in the formation of road safety strategy, and therefore it is of great importance that the analysis of the current state is of the highest quality. Other steps in the formation of road safety strategy are also equally important and significant, starting from defining the key areas, to the formation of action plans, activity plans and the final strategy document at the city level. Especially important for each step is the implementation of the so-called vertical flow of information between the city and the municipalities on the principle of the so-called "top-down" and "bottom-up" approach.

Assessment of the effects of the implementation of measures and actions planned by the strategic document through action plans and activity plans, is an essential part of the process of forming and implementing road safety strategy, because in this way the effects can be monitored and a revision can be done, which involves as a consequence several outputs: continue with the strategy without changes, make minor changes to the strategy, make major changes to the strategy or adopt an entirely new strategy document.

The process of road safety strategy forming presented in this study has been applied on a specific case, the development of road safety strategy for the city of Belgrade. We believe that the applied model for defining the structure and content of the strategic document in road safety is applicable at all levels, from national down to local levels. During the work on the creation of such a document, it was concluded that the institutional strengthening is the basis for the formation and subsequent implementation of road safety strategy. By involving stakeholders in the development of a strategic 
document, a favorable climate for acceptance and implementation of activities envisaged by the strategy is created, ensuring that road safety strategy would be sustainable.

\section{Acknowledgements}

This paper is based on the project TR36027: "Software development and national database for strategic management and development of transportation means and infrastructure in road, rail, air and inland waterways transport using the European transport network models" which is supported by the Ministry of education, science and technological development of the Republic of Serbia (2011-2014).

\section{References}

Bener, A.; Abu-Zidan, F.M.; Bensiali, A.K.; Al-Mulla, A.A.K.; Jadaan, K.S. 2003. Strategy to improve road safety in developing countries, Saudi Medical Journal, 24(6): 603 608.

Broughton, J.; Allsop, R.E.; Lynam, D.A.; McMahon, C.M. 2000. The Numerical Context for Setting National Casualty Reduction Targets. Report No. 382 (Crowthorne: TRL).

Dorset County Council. 2009. Traffic Safety Plan 20102020: "Making road travel in Dorset the safest in the region".

Elvik, R. 1993. Quantified road safety targets: a useful tool for policy-making?, Accident Analysis and Prevention. DOI: http://dx.doi.org/10.1016/0001-4575(93)90009-L, 25(5): 569-583.

Elvik, R. 2001. Quantified Road Safety Targets: An Assessment of Evaluation Methodology. Report No. 539/2001 (Oslo: Institute of Transport Economics).

Elvik, R.; Vaa, T. 2004. The Handbook of Road Safety Measures. Elsevier.
Elvik, R. 2008. Road safety management by objectives: A critical analysis of the Norwegian approach, Accident Analysis and Prevention. DOI: http://dx.doi.org/10.1016/j. aap.2007.12.002, 40(3): 1115-1122.

European Transport Safety Council (ETSC). 2001. A Strategy for EU Transport Safety Research.

European Transport Safety Council (ETSC). 2003. Assessing Risk and Setting Targets in Transport Safety Programmes.

Kölbl, R.; Niegl, M.; Knoflacher, H. 2008. A strategic planning methodology, Transport Policy. DOI: http://dx.doi. org/10.1016/j.tranpol.2008.07.001, 15(5): 273-282.

Loo, B.Y.P.; Hung, W.T.; Lo, H.K.; Wong, S.C. 2005. Road Safety Strategies: A Comparative Framework and Case Studies, Transport Reviews. DOI: http://dx.doi. org/10.1080/01441640500115892, 25(5): 613-639.

Ministry of interior and public administration of Montenegro (MoIaPA). 2009. Strategija poboljšanja bezbednosti saobraćaja (2010-2019) (eng. Road safety improvement strategy (20102019)), Podgorica. Available from Internet: <http://www. mup.gov.me/ResourceManager/FileDownload.aspx?rid $=41601 \&$ rType $=2 \&$ file $=1264511606 . \mathrm{doc}>$.

Ministry of interior of Republic of Serbia (MoIRS). 2009. Zakon o bezbednosti saobraćaja na putevima, Sl.glasnik br. 41/09 i No. 53/10 (eng. Traffic safety law on roads, No. $41 / 09$ and No. 53/10).

Pešić, D.; Vujanić, M.; Lipovac, K.; Antić, B. 2012. Integrated method of identifying and ranking danger spots for pedestrians on microlocation, Transport. DOI: http:// dx.doi.org/10.3846/16484142.2012.664826 27(1): 49-59.

Republic Council for Road Safety (RCRS). 2008. National Strategy of the Republic of Macedonia for Improvement of the Road Traffic Safety 2009-2014, Skopje.

World Road Association (PIARC). 2004. Road Safety Manual. $603 \mathrm{p}$. 
Rumar, K. 2002. Road safety work: problems, strategies and visions. In S.C. Wong, W.T. Hung and H.K. Lo (eds.) Road Safety-Strategy and Implementation. China Public Security Publisher, Shenzhen, China. 1-17.

SafetyNet. 2009a. Quantitative road safety targets, retrieved 20.09.2010.

SafetyNet. 2009b. Work-related road safety, retrieved 20.09.2010.

Timms, P.M.; May, A.D.; Shepherd, S.P. 2002. The sensitivity of optimal transport strategies to specification of objectives, Transportation Research Part A: Policy and Practice. DOI: http://dx.doi.org/10.1016/S09658564(01)00009-X, 36(5): 383-401.

Timms, P. 2011. Urban transport policy transfer: "bottomup" and "top down" perspectives, Transport Policy. DOI: http://dx.doi.org/10.1016/j.tranpol.2010.10.009, 18(3): 513-521.

Vujanić, M.; Lipovac, K.; Jovanović, D.; Pešić, D.; Antić, B. 2011. Projekat: Strategija grada Beograda o bezbednosti saobraćaja (eng. Project: Road safety strategy for city of Belgrade). University of Belgrade, The Faculty for traffic and transport engeenering, Belgrade.

Wegman, F.; Vanselm, J.; Herweijer, M. 1991. Evaluation of a stimulation plan for municipalities in the Netherlands, Safety Science. DOI: http://dx.doi.org/10.1016/09257535(91)90015-E, 14(1): 61-73.

Wong, S.C.; Leung, B.S.Y.; Becky, P.Y.L.; Hung, W.T.; Hong, K.L. 2004. A qualitative assessment methodology for road safety policy strategies, Accident Analysis and Prevention. DOI: http://dx.doi.org/10.1016/S00014575(03)00006-X, 36(2): 281-293.

Wong, S.C.; Sze, N.N.; Yip, H.P.; Loo, B.P.Y.; Hung, W.T.; Hong, K.L. 2006. Association between setting quantified road safety targets and road fatality reduction, Accident Analysis and Prevention. DOI: http://dx.doi.org/10.1016/j. aap.2006.04.003, 38(5): 997-1005.
World Bank Group (WBG). 2008. Preparing a national transport strategy: Suggestions for Government Agencies in Developing Countries. Transport Sector Board. Washington DC.

World Health Organization (WHO). 2009. Global status report on road safety: Time for action.

World Health Organization, FIA foundation and World Bank (WHO). 2010. A Road Safety Manual for DecisionMakers and Practitioners.

Zhang, X.; Paulley, N.; Hudson, M.; Rhys-Tyler, G. 2006. A method for the design of optimal transport strategies, Transport Policy. DOI: http://dx.doi.org/10.1016/j. tranpol.2005.12.006, 13(4): 329-338.

\section{jitte 202}




\section{“BOTTOM-UP" I 'TOP-DOWN" PRISTUP DEFINISANJA STRATEGIJE BEZBEDNOSTI SAOBRAĆAJA - STUDIJA SLUČAJA: BEOGRAD}

\section{Milan Vujanić, Krsto Lipovac, Dragan \\ Jovanović, Dalibor Pešić, Boris Antić}

Sažetak: Proces formiranja strategije bezbednosti saobraćaja je vrlo složen jer podrazumeva sistemski pristup koji se sastoji od nekoliko manje ili više složenih koraka. Analiza postojećeg stanja, definisanje problema i kreiranje strateškog dokumenta su osnovni koraci u formiranju strategije bezbednosti saobraćaja. Svaki od navedenih koraka podrazumeva nekoliko aktivnosti koje se moraju sprovesti. Praćenje efekata realizacije i revizija su naredni koraci u životnom ciklusu strategije koji omogućavaju kontinuirano praćenje i prilagođavanje akcija i programa za unapređenje bezbednosti saobraćaja. U radu je na primeru strateškog dokumenta za grad Beograd prikazan koncept za definisanje strategije i ključnih oblasti strategije bezbednosti saobraćaja, koji koristi "top-down" i "bottom-up" pristup protoka informacija. Specifičnost kreiranja strategije je bio što se grad Beograd sastoji od 10 urbanih i 7 ruralnih opština, pa je bilo neophodno naći model strateškog dokumenta koji bi obuhvatio sve probleme kako na gradskom nivou, tako i u svih 17 opština. Model predstavljen ovim radom predviđa kreiranje jednog tzv. krovnog strateškog dokumenta i 17 akcionih planova za svaku od opština, a krovni dokument se dobija tzv. "overlap" 17 akcionih planova.

Ključne reči: strategija bezbednosti saobraćaja, analiza bezbednosti saobraćaja, ključne oblasti, ciljevi, akcioni plan, plan aktivnosti, "top-down" $i$ "bottom-up" pristup. 